University of Nebraska - Lincoln

DigitalCommons@University of Nebraska - Lincoln

\title{
Carbon Source Quality and Placement Effects on Soil Organic Carbon Status
}

Brian J. Wienhold

USDA-ARS, Brian.Wienhold@ars.usda.gov

Gary E. Varvel

University of Nebraska-Lincoln, gevarvel@windstream.net

J. M. F. Johnson

USDA-ARS Morris, jjohnson@morris.ars.usda.gov

W. W. Wilhelm

USDA-ARS

Follow this and additional works at: https://digitalcommons.unl.edu/usdaarsfacpub

Wienhold, Brian J.; Varvel, Gary E.; Johnson, J. M. F.; and Wilhelm, W. W., "Carbon Source Quality and Placement Effects on Soil Organic Carbon Status" (2013). Publications from USDA-ARS / UNL Faculty. 1301.

https://digitalcommons.unl.edu/usdaarsfacpub/1301

This Article is brought to you for free and open access by the U.S. Department of Agriculture: Agricultural Research Service, Lincoln, Nebraska at DigitalCommons@University of Nebraska - Lincoln. It has been accepted for inclusion in Publications from USDA-ARS / UNL Faculty by an authorized administrator of DigitalCommons@University of Nebraska - Lincoln. 


\title{
Carbon Source Quality and Placement Effects on Soil Organic Carbon Status
}

\author{
B. J. Wienhold • G. E. Varvel • J. M. F. Johnson • \\ W. W. Wilhelm
}

This article is a U.S. government work, and is not subject to copyright in the United States.

Published online: 1 February 2013

(C) Springer Science+Business Media New York (outside the USA) 2013

\begin{abstract}
Improved management of agricultural soils has potential for sequestering carbon (C) and reducing the accumulation of atmospheric carbon dioxide. Development of management practices to increase $\mathrm{C}$ sequestration is dependent on improved understanding of soil processes influencing long-term storage of $\mathrm{C}$. A field study was conducted to compare surface $\mathrm{C}$ source quality and above- vs. belowground addition of annual or perennial plant biomass effects on particulate organic matter (POM), total labile C (TLC), and total organic C (TOC). Since microaggregate stabilization within macroaggregates is the main mechanism for sequestering $\mathrm{C}$, aggregate size distribution, expressed as mean weight diameter (MWD), and wet aggregate stability (WAS) was also measured. After 5 years, POM decreased in plots receiving surface application of readily available substrate (sucrose and alfalfa pellets) and the bare surface control. Plots receiving plant additions [wood chips, growing wheat (Triticum aestivum L.) crop, growing switchgrass (Panicum virgatum L.) crop, and fallow receiving either wheat or switchgrass residue] exhibited higher TLC and TOC content. Plots receiving plant residue maintained MWD, and those supporting live plants exhibited increasing WAS. Surface plant residue protected the soil against raindrop impact and reduced the intensity of wetting and drying cycles allowing the development of larger more stable aggregates resulting in $\mathrm{C}$ accrual.
\end{abstract}

USDA is an equal opportunity provider and employer.

B. J. Wienhold $(\bowtie) \cdot$ G. E. Varvel $\cdot$ W. W. Wilhelm

USDA-ARS, 137 Keim Hall, East Campus, UNL,

Lincoln, NE 68583, USA

e-mail: Brian.Wienhold@ars.usda.gov

J. M. F. Johnson

USDA-ARS, Morris, MN, USA
Keywords Carbon sequestration · Soil structure · Plant residue $\cdot$ Soil aggregation

\section{Introduction}

Crop residue and perennial grasses have been identified as potential feedstock for biofuel production [12] and are currently used for animal feed. Aboveground residue protects soils from potential wind and water erosion, serves as a boundary layer reducing evaporation, and serves as a substrate for soil biota. Removing plant residue raises concerns regarding soil conservation, soil organic matter, compaction, and future soil fertility [21]. Efforts have been made to determine the amount of residue that must be retained to sustain soils [22]. The effect of removing plant residue components on water erosion [19] and soil fertility [20] has also been studied. Information regarding the role of plant residue in sustaining soil biota and processes effecting carbon (C) sequestration are lacking.

Plant residue is utilized by soil biota as an energy and nutrient source. The process of plant residue decomposition results in carbon dioxide emission from soils. The long-term accrual of $\mathrm{C}$ in soils occurs when the $\mathrm{C}$ becomes unavailable to soil microorganisms. Sequestered C can be chemically or physically protected [13]. The general mechanism by which residue is sequestered in soils involves formation of macroaggregates around residue particles and the entrapment of these coarse particles by soil particles and microbial by-products forming microaggregates within macroaggregates. Macroaggregates eventually break down releasing microaggregates which are then available to form new macroaggregates [14]. Eventually, $\mathrm{C}$ in microaggregates becomes adsorbed to the mineral phase or 
physically protected within interaggregate pores that cannot be accessed by decomposers (e.g., [13]). It is the turnover of macroaggregate stable microaggregates that results in accrual of soil C.

Soil microorganisms are able to utilize diverse substrates for growth. Low-quality substrates favor fungi while highquality substrates favor bacteria [3]. Fungi produce byproducts that decompose more quickly than bacterially produced by-products [8]. The composition of substrate also affects the rate at which it is decomposed by microorganisms [5]. Hence, the placement and quality of $\mathrm{C}$ substrate influence the soil microbial community and its activity, and may influence the microbially produced by-products involved in the aggregation process. The objective of this study was to compare aggregation and aggregate stability and components of soil organic matter in soils receiving $\mathrm{C}$ sources of varying quality and placement.

\section{Materials and Methods}

\section{Site Description and Experimental Design}

The field site was located at the Roger's Memorial Research Farm $10 \mathrm{~km}$ east of Lincoln, NE. Soil at this site is a Aksarben silty clay loam (fine, smectitic, mesic Typic Argiudolls) on a 3 to $5 \%$ slope. Annual precipitation at the site averages $723 \mathrm{~mm}$. The site has been in a no-tillage winter wheat (Triticum aestivum L.), soybean (Glycine max [L.] Merr.), and sorghum (Sorghum bicolor [L.] Moench) rotation for $>10$ years before initiation of this study. The experiment was initiated in November 2002. The experimental design was a randomized blocks design with four replications. Plot size was 4.6 by $4.6 \mathrm{~m}$. Treatments represent $\mathrm{C}$ sources of varying quality. The 12 treatments included: wood chips (high lignin content), alfalfa pellets (low $\mathrm{C} / \mathrm{N}$ ratio), sucrose, wheat flour, paper (three sources having high $\mathrm{C} / \mathrm{N}$ ratios and differing in solubility of the $\mathrm{C}$ ), control (fallow, no $\mathrm{C}$ added), three annual crop plots [wheat grown and aboveground residue returned at harvest $(\mathrm{WR}+)$, wheat grown and aboveground residue removed at harvest (WR-), and fallow with wheat residue added at harvest (fallow $\mathrm{WR}+$ )], and three perennial crop treatments [switchgrass (Panicum virgatum $\mathrm{L}$.) grown and aboveground residue returned at harvest $(\mathrm{SR}+)$, switchgrass grown and aboveground residue removed at harvest (SR-), and fallow with switchgrass residue added at harvest (fallowSR+)]. Carbon sources, including wheat and switchgrass residue, were applied at a rate of $0.54 \mathrm{~kg}$ dry matterm ${ }^{-2}$ to each plot when wheat was harvested. This rate is similar to the amount of $\mathrm{C}$ contained in wheat residue that would be returned to the soil assuming the longterm wheat yield (3.2 $\mathrm{Mg}_{\text {grainha }}{ }^{-1}$ ) for the site. Weeds were controlled using glyphosate in non-vegetative plots and hand weeding in wheat and switchgrass plots.
The annual (WR+, WR-, and fallowWR + ) and perennial (SR+, $\mathrm{SR}_{-}^{-}$, and fallowSR+) crop plots were included to separate the effects of aboveground and belowground $\mathrm{C}$ inputs. The crop plots having aboveground residue returned at harvest $(\mathrm{WR}+$ and $\mathrm{SR}+$ ) received both above- and belowground $\mathrm{C}$, the plots having aboveground residue removed at harvest (WR- and $\mathrm{SR}-$ ) received only belowground $\mathrm{C}$, and the plots in fallow and receiving residue at harvest (fallowWR + and fallowSR + ) received only aboveground C. Trailblazer switchgrass was planted June 5, 2003, and was harvested following a frost (November) in subsequent years. At harvest, aboveground biomass was removed from switchgrass plots, weighed, a 10-g subsample collected for determination of moisture content, and redistributed on the appropriate plots. Winter wheat was planted in October each year and harvested at maturity (July) the following summer of each year. At harvest, aboveground biomass was removed from wheat plots, thrashed to remove grain, weighed, a 10-g subsample collected for determination of moisture content, and straw redistributed on the appropriate plots. Switchgrass and wheat received annual applications of $\mathrm{N}$ as $\mathrm{NH}_{4} \mathrm{NO}_{3}$ at a rate of $45 \mathrm{kgha}^{-1}$.

\section{Soil Sampling and Analysis}

In November 2002 and July 2007, a 5.7-cm-diameter soil core was taken to a depth of $90 \mathrm{~cm}$ within each plot. Sampling in 2002 occurred prior to planting wheat and application of C source treatments. Sampling in 2007 occurred just after wheat harvest. The core was sectioned into 0- to 7.5-, 7.5- to 15-, 15to $30-, 30-$ to $60-$, and $60-$ to $90-\mathrm{cm}$ increments. Soil samples were stored at $5{ }^{\circ} \mathrm{C}$ until they were analyzed for biological properties. Remaining soil was air-dried, ground, passed through a 2-mm sieve, and stored at room temperature until it was analyzed for chemical properties.

Soil physical properties measured included bulk density (BD). Bulk density was calculated for each depth increment by dividing the mass of soil, corrected for moisture content, by the volume of soil collected [2]. Soil chemical properties measured for all depth increments included $\mathrm{pH}$, electrical conductivity (EC), organic $\mathrm{C}$, and total $\mathrm{N}$. Total labile $\mathrm{C}$ (TLC) and particulate organic matter (POM) were determined for the $0-$ to $7.5-$ and 7.5 - to $15-\mathrm{cm}$ depth increments only. Distilled water was added on a 1:1 $w / w$ basis to $10 \mathrm{~g}$ of air-dried soil, EC of the soil slurry was determined using a conductivity meter, and $\mathrm{pH}$ was then determined using a glass electrode [15]. Total $\mathrm{C}$ and $\mathrm{N}$ were determined by dry combustion using a Thermo Flash EA NC Soil Analyzer (Thermo Finnegan Scientific Inc., Waltham, MA). Carbonates were not present based on treatment of the soil with dilute acid, and total $\mathrm{C}$ was assumed to represent organic $\mathrm{C}$. Total labile $\mathrm{C}$ was measured using the $\mathrm{KMnO}_{4}$ oxidation method [18]. Particulate organic matter in the 


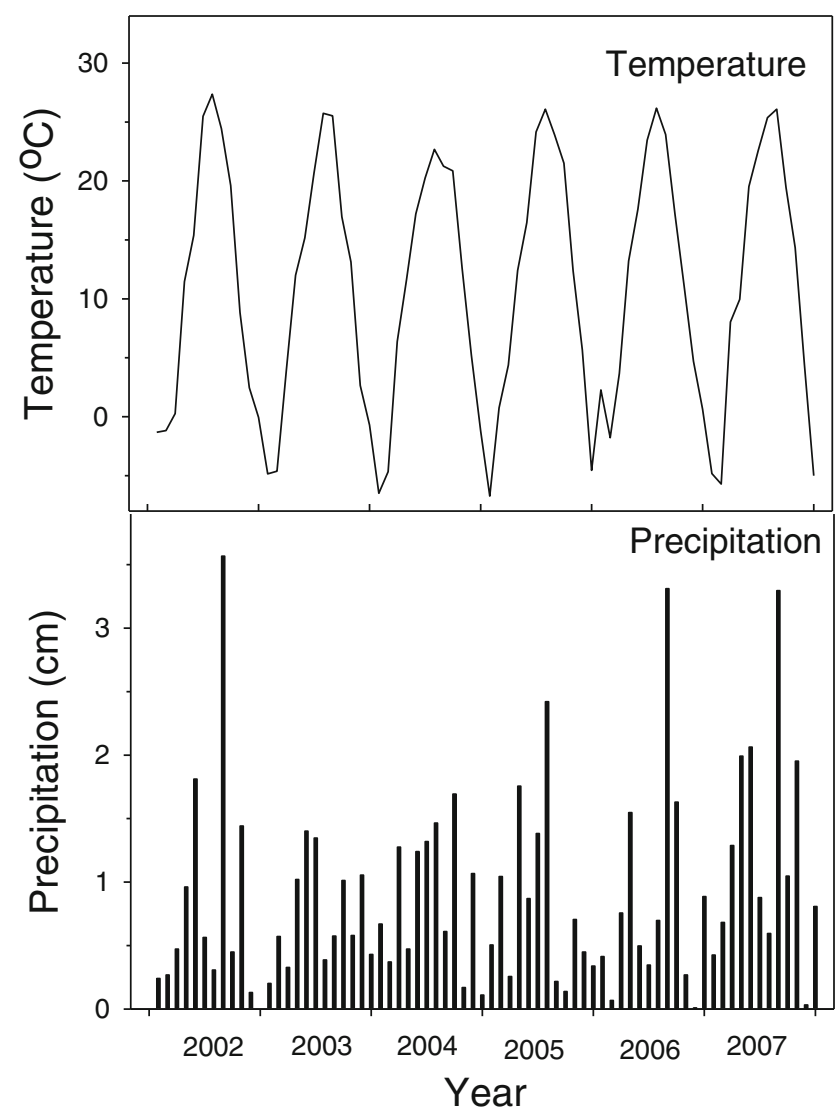

Fig. 1 Average daily temperature and monthly precipitation distribution from 2002 to 2007 for the study site in eastern Nebraska

$<0.5$-mm and 0.5 - to 2 - $\mathrm{mm}$ fractions was determined using the method of Cambardella et al. [4]. Soil chemical and biological properties are reported on a volumetric basis and were calculated using measured BD values. Results are reported as treatment means \pm standard error of the mean.

Each year from 2002 to 2007, a shovel was used to collect a bulk soil sample from the 0- to 7.5- and 7.5- and $15-\mathrm{cm}$ depths for determination of aggregate size distribution and wet aggregate stability (WAS). Bulk samples were air-dried and gently broken apart to pass through an 8-mm sieve. Aggregate size distribution was determined by passing the bulk soil sample through a set of nested sieves using a Ro-Tap model B shaker (Soil Test Inc., Evanston, IL) to agitate the samples for $1 \mathrm{~min}$ [6]. Sieve openings were 2, 1, 0.5 , and $0.053 \mathrm{~mm}$ resulting in aggregate fractions of $>2 \mathrm{~mm}, 1$ to $2 \mathrm{~mm}, 0.5$ to $1 \mathrm{~mm}, 0.053$ to $0.5 \mathrm{~mm}$, and $<0.053 \mathrm{~mm}$. Aggregate size distribution was expressed as mean weight diameter (MWD). Wet aggregate stability was determined for the $>2 \mathrm{~mm}, 1$ to $2 \mathrm{~mm}$, and 0.5 to $1 \mathrm{~mm}$ aggregate size fractions by placing aggregates within each size fraction on a sieve, capillary wetting aggregates with distilled water, and agitating the samples on a wet sieve shaker (Five Star Scientific, Twin Falls, ID) for 5 min [6].
Aggregates remaining on the sieve were oven dried and mass determined.

In 2005, in situ soil respiration was measured in each plot on five dates during the growing season (June 22, July 8 , July 18 , September 1 , and October 11). A plastic ring was inserted to a depth of $5 \mathrm{~cm}$ in the center of each plot prior to application of the $\mathrm{C}$ sources. Soil respiration was measured using a LiCor 6400 soil $\mathrm{CO}_{2}$ flux chamber (LiCor, Lincoln, $\mathrm{NE}$ ).

In July 2007, two 5.7-cm-diameter cores were collected from the center of each switchgrass and wheat plot to a depth of $45 \mathrm{~cm}$ for determination of root mass and structural carbohydrate analysis. At sampling, switchgrass was at anthesis and wheat was senescing. Soil was washed from roots with water using 2 - and $0.5-\mathrm{mm}$ sieves as described by Smucker et al. [16]. Non-root detritus or shoot material was removed manually. Root samples were then dried at $45{ }^{\circ} \mathrm{C}$ and mass determined [5]. Soluble sugars, starch, hemicellulose, cellulose, acid-soluble lignin, and acidinsoluble lignin were determined by sequential extraction, and identified and quantified using standard biomass analytical methods [9-11].

\section{Statistical Analysis}

Soil attributes were compared among treatments by a randomized blocks repeated measures model in SAS/MIXED ${ }^{\circledR} 1$ [7]. Since soil attributes are known to differ with depth, depth was not included in the statistical model, and separate statistical analyses were performed for each depth increment. Differences were declared significant at the 0.05 probability level. Differences among means were determined by pairwise comparisons made with the DIFF option of the LSMEANS statement. The Tukey adjustment option of the LSMEANS statement was used to protect the experimentwise error rate. Root biomass and structural carbohydrates in wheat and switchgrass plots were compared using a $t$ test with differences declared significant at the 0.05 probability level.

\section{Results}

Temperatures during the study period exhibited a pattern typical for the regions (Fig. 1). Highest temperatures were

\footnotetext{
${ }^{1}$ SAS and all other SAS Institute Inc. product or service names are registered trademarks or trademarks of SAS Institute Inc. in the USA and other countries. ${ }^{\mathbb{B}}$ indicates USA registration.

Mention of trade names or commercial products in this publication is solely for the purpose of providing specific information and does not imply recommendation or endorsement by the US Department of Agriculture.
} 
Table 1 Select physical and chemical properties as a function of year and depth for a carbon source experiment in eastern Nebraska

\begin{tabular}{|c|c|c|c|c|c|c|}
\hline Depth $(\mathrm{cm})$ & Year & $\begin{array}{l}\text { Bulk density } \\
\left(\mathrm{Mgm}^{-3}\right)\end{array}$ & $\begin{array}{l}\text { Electrical conductivity } \\
\left(\mathrm{dS} \mathrm{m}^{-1}\right)\end{array}$ & $\mathrm{pH}$ & $\begin{array}{l}\text { Nitrogen concentration } \\
\left(\mathrm{g} \mathrm{kg}^{-1}\right)\end{array}$ & $\begin{array}{l}\text { Nitrogen content } \\
\left(\mathrm{Mgha}^{-1}\right)\end{array}$ \\
\hline \multirow[t]{3}{*}{0 to 7.5} & 2002 & $0.87 \pm 0.02^{\mathrm{a}}$ & $0.39 \pm 0.01$ & $6.61 \pm 0.04$ & $18.4 \pm 0.3$ & $1.20 \pm 0.03$ \\
\hline & 2007 & $1.24 \pm 0.02$ & $0.38 \pm 0.01$ & $6.31 \pm 0.04$ & $15.8 \pm 0.3$ & $1.46 \pm 0.03$ \\
\hline & & $P<0.0001$ & NS & $P<0.0001$ & $P<0.0001$ & $P<0.0001$ \\
\hline \multirow[t]{3}{*}{7.5 to 15} & 2002 & $1.05 \pm 0.01$ & $0.23 \pm 0.01$ & $5.24 \pm 0.04$ & $14.4 \pm 0.3$ & $1.14 \pm 0.03$ \\
\hline & 2007 & $1.00 \pm 0.01$ & $0.28 \pm 0.01$ & $5.52 \pm 0.04$ & $13.5 \pm 0.3$ & $1.02 \pm 0.03$ \\
\hline & & $P=0.002$ & $P<0.0001$ & $P<0.0001$ & $P=0.03$ & $P=0.003$ \\
\hline \multirow[t]{3}{*}{15 to 30} & 2002 & $1.09 \pm 0.01$ & $0.25 \pm 0.01$ & $5.67 \pm 0.03$ & $10.9 \pm 0.2$ & $1.78 \pm 0.03$ \\
\hline & 2007 & $1.12 \pm 0.01$ & $0.34 \pm 0.01$ & $5.70 \pm 0.03$ & $10.1 \pm 0.2$ & $1.69 \pm 0.03$ \\
\hline & & $P=0.011$ & $P<0.0001$ & NS & $P=0.005$ & $P=0.037$ \\
\hline \multirow[t]{3}{*}{30 to 60} & 2002 & $1.19 \pm 0.01$ & $0.27 \pm 0.01$ & $6.26 \pm 0.03$ & $6.6 \pm 0.1$ & $2.34 \pm 0.07$ \\
\hline & 2007 & $1.19 \pm 0.01$ & $0.36 \pm 0.01$ & $6.09 \pm 0.03$ & $6.6 \pm 0.1$ & $2.38 \pm 0.07$ \\
\hline & & NS & $P<0.0001$ & $P<0.0001$ & NS & NS \\
\hline \multirow[t]{3}{*}{60 to 90} & 2002 & $1.18 \pm 0.01$ & $0.34 \pm 0.02$ & $6.74 \pm 0.05$ & $4.5 \pm 0.1$ & $1.59 \pm 0.03$ \\
\hline & 2007 & $1.20 \pm 0.01$ & $0.42 \pm 0.02$ & $6.49 \pm 0.05$ & $4.6 \pm 0.1$ & $1.67 \pm 0.03$ \\
\hline & & $P=0.003$ & $P<0.0001$ & $P<0.0001$ & NS & NS \\
\hline
\end{tabular}

$P$ values represent the probability of a significant difference between years for a given depth increment

${ }^{\mathrm{a}}$ Mean $\pm \mathrm{SE}$

observed in July and August and lowest temperatures were observed in December and January each year. Growing season temperatures were above average in 2002, 2005, 2006, and 2007; near the average in 2003; and below average in 2004. Monthly precipitation was highly variable but between 64 and $77 \%$ of annual precipitation was received during the April to August time period each year. Annual precipitation was below the long-term average of $723 \mathrm{~mm}$ in all years except 2007.

Wheat yield in the $\mathrm{WR}+$ and $\mathrm{WR}-$ treatments was $2.5 \pm$ $0.2 \mathrm{Mgha}^{-1}$, and straw production was $3.1 \pm 0.3 \mathrm{Mgha}^{-1}$. Switchgrass biomass production in the $\mathrm{SR}+$ and $\mathrm{SR}-$ treatments was $11.7 \pm 1.7 \mathrm{Mgha}^{-1}$. When sampled in 2007, root biomass was greater $(P<0.0001)$ in the $\mathrm{SR}+$ and $\mathrm{SR}-$ treatments $\left(1,615 \pm 133 \mathrm{~g} \mathrm{~m}^{-2}\right)$ than in the WR+ and WR- treatments $\left(306 \pm 48 \mathrm{~g} \mathrm{~m}^{-2}\right)$. Switchgrass roots contained greater amounts of soluble sugars $\left(62.0 \pm 7.6\right.$ vs. $6.5 \pm 1.3 \mathrm{~g} \mathrm{~m}^{-2}, P<$ $0.0001)$, starch $\left(42.0 \pm 8.2\right.$ vs. $\left.1.3 \pm 0.2 \mathrm{gm}^{-2}, P<0.0001\right)$, hemicellulose $\left(288.6 \pm 22.1\right.$ vs. $88.1 \pm 12.7 \mathrm{~g} \mathrm{~m}^{-2}, P<$ $0.0001)$, cellulose $\left(416.7 \pm 46.0\right.$ vs. $83.8 \pm 13.6 \mathrm{~g} \mathrm{~m}^{-2}, P<$ $0.0001)$, acid-insoluble lignin $(389.4 \pm 35.4$ vs. $50.7 \pm 8.9 \mathrm{~g}$ $\left.\mathrm{m}^{-2}, P<0.0001\right)$, acid-soluble lignin $(11.7 \pm 0.9$ vs. $3.0 \pm$ $\left.0.4 \mathrm{~g} \mathrm{~m}^{-2}, P<0.0001\right)$, and ash $(395.9 \pm 42.5$ vs. $72.7 \pm$ $\left.16.1 \mathrm{~g} \mathrm{~m}^{-2}, P<0.0001\right)$ than wheat roots.

Over the 5 -year study, soil bulk density increased $40 \%$ in the 0 to 7.5 depth increment (Table 1). In the 7.5- to 15-, 15to $30-$, and $60-$ to $90-\mathrm{cm}$ depth increments, there were statistically significant changes in bulk density, but the magnitude of the changes was very small. There was no change in bulk density in the 30 - to 60 -cm depth increment. There were no differences in bulk density among $\mathrm{C}$ source treatments in either year.

While soil $\mathrm{C}$ was the main focus of this study, a number of other chemical properties were measured. Electrical conductivity was similar between the 2 years in the 0 - to $7.5-\mathrm{cm}$ depth increment (Table 1). In all other depth increments, EC increased 20 to $36 \%$ from 2002 to 2007 . There were no differences in EC among the $\mathrm{C}$ source treatments. Soil $\mathrm{pH}$ decreased in the $0-$ to $7.5-, 30-$ to $60-$, and $60-$ to $90-\mathrm{cm}$ depth increments and increased in the 7.5- to $15-\mathrm{cm}$ depth increment (Table 1). There was no change in soil $\mathrm{pH}$ in the 15- to 30-cm depth increment. There were no differences in soil $\mathrm{pH}$ among the $\mathrm{C}$ source treatments. Soil $\mathrm{N}$ concentration declined over the 5 years of the study in the 0- to 7.5-, 7.5to $15-$, and $15-$ to $30-\mathrm{cm}$ depth increments and did not change in the two lower soil depth increments (Table 1). Soil N content increased in the $0-$ to $7.5-\mathrm{cm}$ increment, declined in the 7.5- to $15-$ and $15-$ to $30-\mathrm{cm}$ depth increment, and did not change in the two lower soil depth increments (Table 1). There were no differences in soil $\mathrm{N}$ concentration or content among the $\mathrm{C}$ source treatments. Total $\mathrm{N}$ content for the $0-$ to $90-\mathrm{cm}$ profile was $8.1 \pm$ $0.2 \mathrm{Mgha}^{-1}$ and was similar across $\mathrm{C}$ source treatments and years.

Several soil C fractions were measured in this study. In the 0 - to $7.5-\mathrm{cm}$ depth increment, POM exhibited a treatment by year interaction $(P=0.0326)$. All treatments had similar POM content at the beginning of the experiment 
Table 2 Total particulate organic matter, total labile carbon, and total organic carbon content for the 0 - to 7.5 -cm soil depth as a function of carbon source for a carbon source experiment in eastern Nebraska

\begin{tabular}{|c|c|c|c|c|c|c|}
\hline \multirow[t]{2}{*}{ Treatment } & \multicolumn{2}{|c|}{ Total particulate organic matter $\left(\mathrm{Mgha}^{-1}\right)$} & \multicolumn{2}{|c|}{ Total labile carbon $\left(\mathrm{Mgha}^{-1}\right)$} & \multicolumn{2}{|c|}{ Total organic carbon $\left(\mathrm{Mgha}^{-1}\right)$} \\
\hline & 2002 & 2007 & 2002 & 2007 & 2002 & 2007 \\
\hline Wood & $6.3^{ \pm} 1.0 \mathrm{aA}^{\mathrm{a}}$ & $5.4^{ \pm} 1.0 \mathrm{aA}$ & $3.0^{ \pm} 0.2 \mathrm{aA}$ & $3.8^{ \pm} 0.2 \mathrm{abB}$ & $13.1^{ \pm} 1.4 \mathrm{aA}$ & $16.4^{ \pm} 1.4 \mathrm{bB}$ \\
\hline Alfalfa & $7.2^{ \pm} 1.0 \mathrm{aB}$ & $3.0^{ \pm} 1.0 \mathrm{aA}$ & $3.0^{ \pm} 0.2 \mathrm{aA}$ & $3.3^{ \pm} 0.2 \mathrm{aA}$ & $13.3^{ \pm} 1.4 \mathrm{aA}$ & $10.7^{ \pm} 1.4 \mathrm{aA}$ \\
\hline Flour & $6.3^{ \pm} 1.0 \mathrm{aA}$ & $3.7^{ \pm} 1.0 \mathrm{aA}$ & $3.0^{ \pm} 0.2 \mathrm{aA}$ & $3.3^{ \pm} 0.2 \mathrm{aA}$ & $13.4^{ \pm} 1.4 \mathrm{aA}$ & $15.1^{ \pm} 1.4 \mathrm{bA}$ \\
\hline Paper & $7.1^{ \pm} 1.0 \mathrm{aA}$ & $4.7^{ \pm} 0.8 \mathrm{aA}$ & $3.2^{ \pm} 0.2 \mathrm{aA}$ & $3.5^{ \pm} 0.2 \mathrm{aA}$ & $14.5^{ \pm} 1.4 \mathrm{aA}$ & $16.1^{ \pm} 1.4 \mathrm{bA}$ \\
\hline Sucrose & $5.8^{ \pm} 1.0 \mathrm{aB}$ & $2.8^{ \pm} 1.0 \mathrm{aA}$ & $2.8^{ \pm} 0.2 \mathrm{aA}$ & $2.9^{ \pm} 0.2 \mathrm{aA}$ & $12.5^{ \pm} 1.4 \mathrm{aA}$ & $13.6^{ \pm} 1.4 \mathrm{abA}$ \\
\hline Control & $7.7^{ \pm} 1.0 \mathrm{aB}$ & $4.0^{ \pm} 1.0 \mathrm{aA}$ & $3.2^{ \pm} 0.2 \mathrm{aA}$ & $3.4^{ \pm} 0.2 \mathrm{aA}$ & $15.0^{ \pm} 1.4 \mathrm{aA}$ & $15.7^{ \pm} 1.4 \mathrm{bA}$ \\
\hline $\mathrm{WR}+$ & $6.8^{ \pm} 1.0 \mathrm{aA}$ & $7.6^{ \pm} 1.0 \mathrm{aA}$ & $3.0^{ \pm} 0.2 \mathrm{aA}$ & $4.1^{ \pm} 0.2 \mathrm{bB}$ & $14.0^{ \pm} 1.4 \mathrm{aA}$ & $19.2^{ \pm} 1.4 \mathrm{bB}$ \\
\hline WR- & $6.3^{ \pm} 1.0 \mathrm{aA}$ & $4.9^{ \pm} 1.0 \mathrm{aA}$ & $3.0^{ \pm} 0.2 \mathrm{aA}$ & $3.7^{ \pm} 0.2 \mathrm{abB}$ & $12.9^{ \pm} 1.4 \mathrm{aA}$ & $14.6^{ \pm} 1.4 \mathrm{abA}$ \\
\hline FWR+ & $6.5^{ \pm} 1.0 \mathrm{aB}$ & $3.2^{ \pm} 1.0 \mathrm{aA}$ & $3.0^{ \pm} 0.2 \mathrm{aA}$ & $3.7^{ \pm} 0.2 \mathrm{abB}$ & $14.2^{ \pm} 1.4 \mathrm{aA}$ & $14.3^{ \pm} 1.4 \mathrm{abA}$ \\
\hline $\mathrm{SR}+$ & $6.7^{ \pm} 1.0 \mathrm{aA}$ & $9.1^{ \pm} 1.0 \mathrm{bA}$ & $3.1^{ \pm} 0.2 \mathrm{aA}$ & $4.4^{ \pm} 0.2 \mathrm{bB}$ & $13.3^{ \pm} 1.4 \mathrm{aA}$ & $17.5^{ \pm} 1.4 \mathrm{bB}$ \\
\hline $\mathrm{SR}-$ & $8.1^{ \pm} 1.0 \mathrm{aA}$ & $8.0^{ \pm} 1.0 \mathrm{abA}$ & $3.2^{ \pm} 0.2 \mathrm{aA}$ & $4.4^{ \pm} 0.2 \mathrm{bB}$ & $14.7^{ \pm} 1.4 \mathrm{aA}$ & $20.1^{ \pm} 1.4 \mathrm{bB}$ \\
\hline FSR+ & $6.4^{ \pm} 1.0 \mathrm{aA}$ & $5.2^{ \pm} 1.0 \mathrm{aA}$ & $2.9^{ \pm} 0.2 \mathrm{aA}$ & $4.2^{ \pm} 0.2 \mathrm{bB}$ & $12.9^{ \pm} 1.4 \mathrm{aA}$ & $16.7^{ \pm} 1.4 \mathrm{bA}$ \\
\hline
\end{tabular}

Treatments: $W R+$ wheat grown and residue returned after harvest, $W R-$ wheat grown and residue removed after harvest, $F W R+$ fallow plots with wheat residue added at harvest, $S R+$ switchgrass grown and residue returned at harvest, $S R-$ switchgrass grown and residue removed at harvest, $F S R+$ fallow plots with switchgrass residue added at harvest

${ }^{a}$ Mean \pm SE; values within a column followed by different lowercase letters are different at $P<0.05$; values within a row for each soil carbon fraction followed by different uppercase letters are different at $P<0.05$

(Table 2). In 2007, POM was greater in the two treatments where switchgrass was grown than in the remaining treatments. From 2002 to 2007, POM declined in the alfalfa, sucrose, control, and fallowWR+ treatments. In the remaining treatments, there was no change in POM between years. In the 7.5- to $15-\mathrm{cm}$ depth increment, there was a significant time effect $(P<0.0001)$ with soil POM declining from 2002 $\left(2.4 \pm 0.1 \mathrm{Mgha}^{-1}\right)$ to $2007\left(1.5 \pm 0.1 \mathrm{Mgha}^{-1}\right)$, but there were no differences among the $\mathrm{C}$ source treatments.

Total labile $\mathrm{C}$ in the $0-$ to $7.5-\mathrm{cm}$ depth increment exhibited a year by treatment interaction $(P=0.048)$. In 2002 , there were no differences among treatments (Table 2). In 2007, TLC was greater in the wood, the three wheat treatments, and the three switchgrass treatments than in the alfalfa, flour, paper, sucrose, and control treatments. Total labile C increased from 2002 to 2007 in the wood, three wheat treatments, and three switchgrass treatments. In the 7.5- to $15-\mathrm{cm}$ depth increment TLC declined (significant time effect, $P=0.0008)$ from $2002\left(2.4 \pm 0.1 \mathrm{Mgha}^{-1}\right)$ to $2007\left(2.1 \pm 0.1 \mathrm{Mgha}^{-1}\right)$ with no differences among the C source treatments.

Soil $\mathrm{C}$ concentration exhibited a treatment by year interaction $(P=0.003)$ in the 0 - to $7.5-\mathrm{cm}$ depth increment, a year effect $(P<0.001)$ in the 7.5 - to $15-\mathrm{cm}$ depth increment, a year effect $(P=0.005)$ in the 15 - to 30 -cm depth increment, no differences in the 30 - to $60-\mathrm{cm}$ depth increment, and a year effect $(P=0.031)$ in the 60 - to $90-\mathrm{cm}$ depth increment (data not shown). Soil $\mathrm{C}$ content exhibited a year by treatment interaction $(P=0.009)$ in the 0 - to $7.5-\mathrm{cm}$ depth increment (Table 2). In 2002, soil C content was similar among the treatments. In 2007, soil C content was greater in the wood, WR+, SR+, and SR- treatments than in 2002 with no differences between years for the remaining $C$ source treatments. In the $7.5-$ to $15-\mathrm{cm}$ depth increment, soil C content decreased from $12.0 \pm 0.2 \mathrm{Mgha}^{-1}$ in 2002 to $10.5 \pm 0.2 \mathrm{Mgha}^{-1}$ in 2007 (year effect, $P<0.0001$ ). In the 15- to 30-cm depth increment, soil $\mathrm{C}$ content decreased from $18.0 \pm 0.3 \mathrm{Mgha}^{-1}$ in 2002 to $16.4 \pm 0.3 \mathrm{Mgha}^{-1}$ in 2007 (year effect, $P<0.0001$ ). There were no differences in $\mathrm{C}$ content $\left(19.8 \mathrm{Mgha}^{-1}\right)$ between years in the 30 - to $60-\mathrm{cm}$ depth increment. In the 60 - to $90-\mathrm{cm}$ depth increment, soil C content increased from $11.0 \pm 0.2 \mathrm{Mgha}^{-1}$ in 2002 to $11.8 \pm$ $0.2 \mathrm{Mgha}^{-1}$ in 2007 (year effect, $P=0.002$ ). There were no differences in $\mathrm{C}$ content among $\mathrm{C}$ source treatments below $15 \mathrm{~cm}$. Total $\mathrm{C}$ content for the 0 - to $90-\mathrm{cm}$ profile $(74.4 \mathrm{Mg}$ $\mathrm{ha}^{-1}$ ) was similar between years and across $\mathrm{C}$ source treatments.

In the $0-$ to $7.5-\mathrm{cm}$ depth increment, aggregate MWD exhibited a year by treatment interaction $(P<0.0001)$. In the wood, alfalfa, flour, paper, sucrose, and control $\mathrm{C}$ source treatments aggregate MWD declined from 2002 to 2004, increased in 2005, and then declined further in 2006 and 2007 (Fig. 2). Among these six C source treatments, aggregate MWD was similar among years except in 2005 when aggregate MWD in the paper treatment was slightly greater than in the other five $\mathrm{C}$ source treatments. In the WR+ 


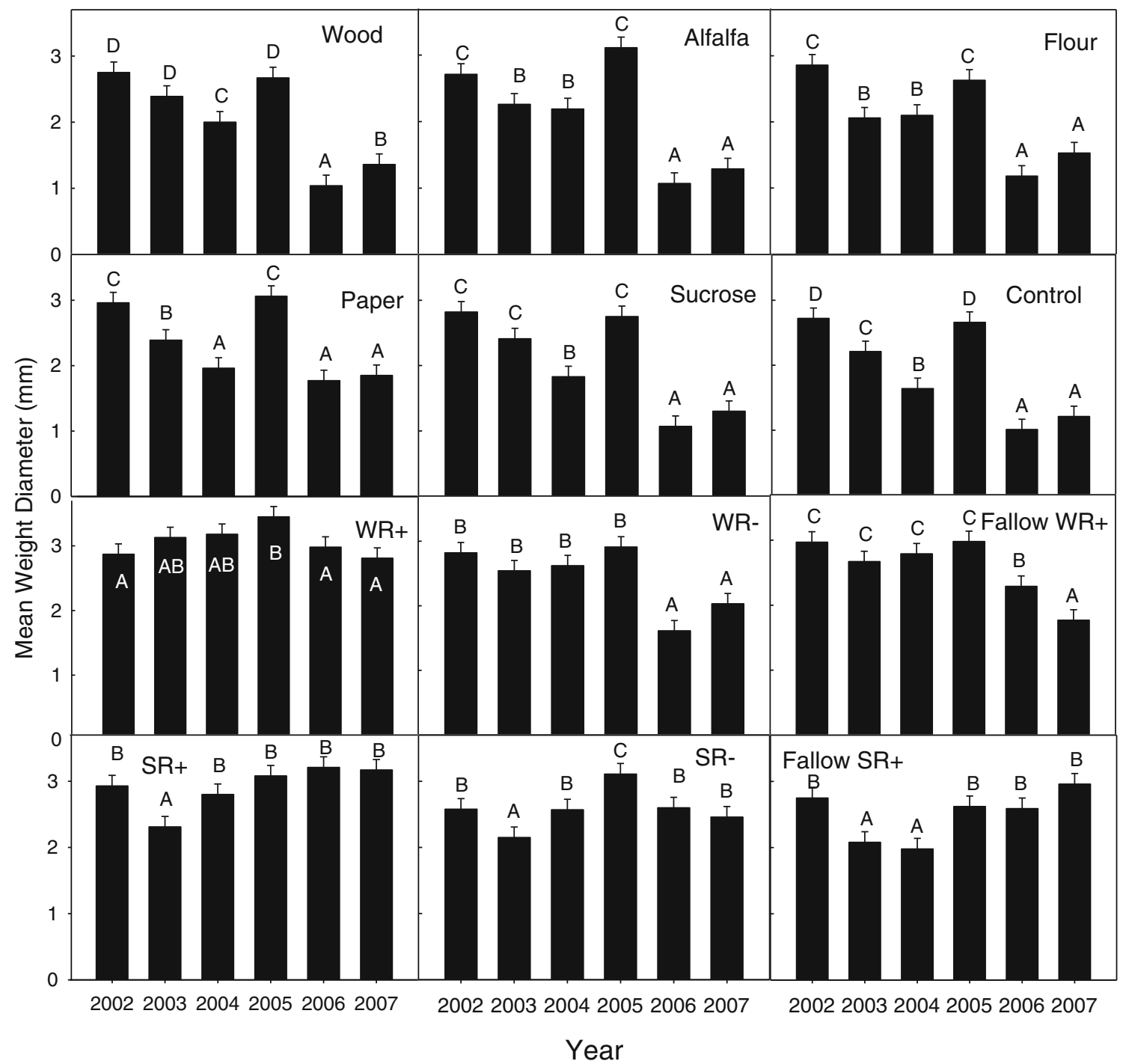

Fig. 2 Mean weight aggregate diameter in the $0-$ to $7.5-\mathrm{cm}$ soil depth as a function of time and carbon source

treatment aggregate, MWD was relatively stable increasing slightly from 2002 to 2005 and declining slightly from 2005 to 2007 with the overall result being no change over the course of the study. In the WR- and fallowWR+ treatments, aggregate MWD did not change from 2002 to 2005 but then declined in 2006 and 2007. In the SR+, SR-, and fallowSR+ treatments, aggregate MWD declined from 2002 to 2003 and then increased from 2003 to 2007 with the net effect being no change in aggregate MWD over the course of the study. Among $\mathrm{C}$ source treatments, aggregate MWD was similar in 2002 but was greater in $\mathrm{WR}+, \mathrm{WR}-$, fallowWR + , $\mathrm{SR}+, \mathrm{SR}-$, and fallowSR + than in the other six $\mathrm{C}$ sources in 2007. In the 7.5- to $15-\mathrm{cm}$ soil depth increment, aggregate MWD was greatest in $2002(3.41 \pm 0.03 \mathrm{~mm})$, declined in $2003(3.20 \pm 0.03 \mathrm{~mm})$ and $2004(2.98 \pm 0.03 \mathrm{~mm})$, increased in $2005(3.33 \pm 0.03 \mathrm{~mm})$ and $2006(3.26 \pm 0.03 \mathrm{~mm})$, and declined in $2007(3.15 \pm 0.03 \mathrm{~mm})$ resulting in a year effect
$(P<0.0001)$. There were no differences in aggregate MWD among the $\mathrm{C}$ source treatments in the $7.5-$ to $15-\mathrm{cm}$ soil depth increment.

In the 0 - to $7.5-\mathrm{cm}$ soil depth increment, WAS in the 0.5 - to 1-mm aggregate size class increased from 2002 to 2007 across $\mathrm{C}$ source treatments (Fig. 3). In the 1- to 2-mm aggregate size class, WAS exhibited a year by treatment interaction $(P<$ 0.001) with WAS increasing from 2002 to 2007 in the paper, sucrose, control, WR+, WR-, fallowWR+, SR+, and SRtreatments compared to no change in WAS from 2002 to 2007 in the remaining $\mathrm{C}$ source treatments. In the $>2-\mathrm{mm}$ aggregate size class, WAS exhibited a year by treatment interaction $(P<0.0001)$ with WAS decreasing from 2002 to 2007 in the wood, flour, and sucrose $C$ source treatments; not changing in the alfalfa, control, and fallowSR $+\mathrm{C}$ source treatments; and increasing in the paper, $\mathrm{WR}+, \mathrm{WR}-$, fallowWR+, $\mathrm{SR}+$, and $\mathrm{SR}-$ carbon source treatments. In the 


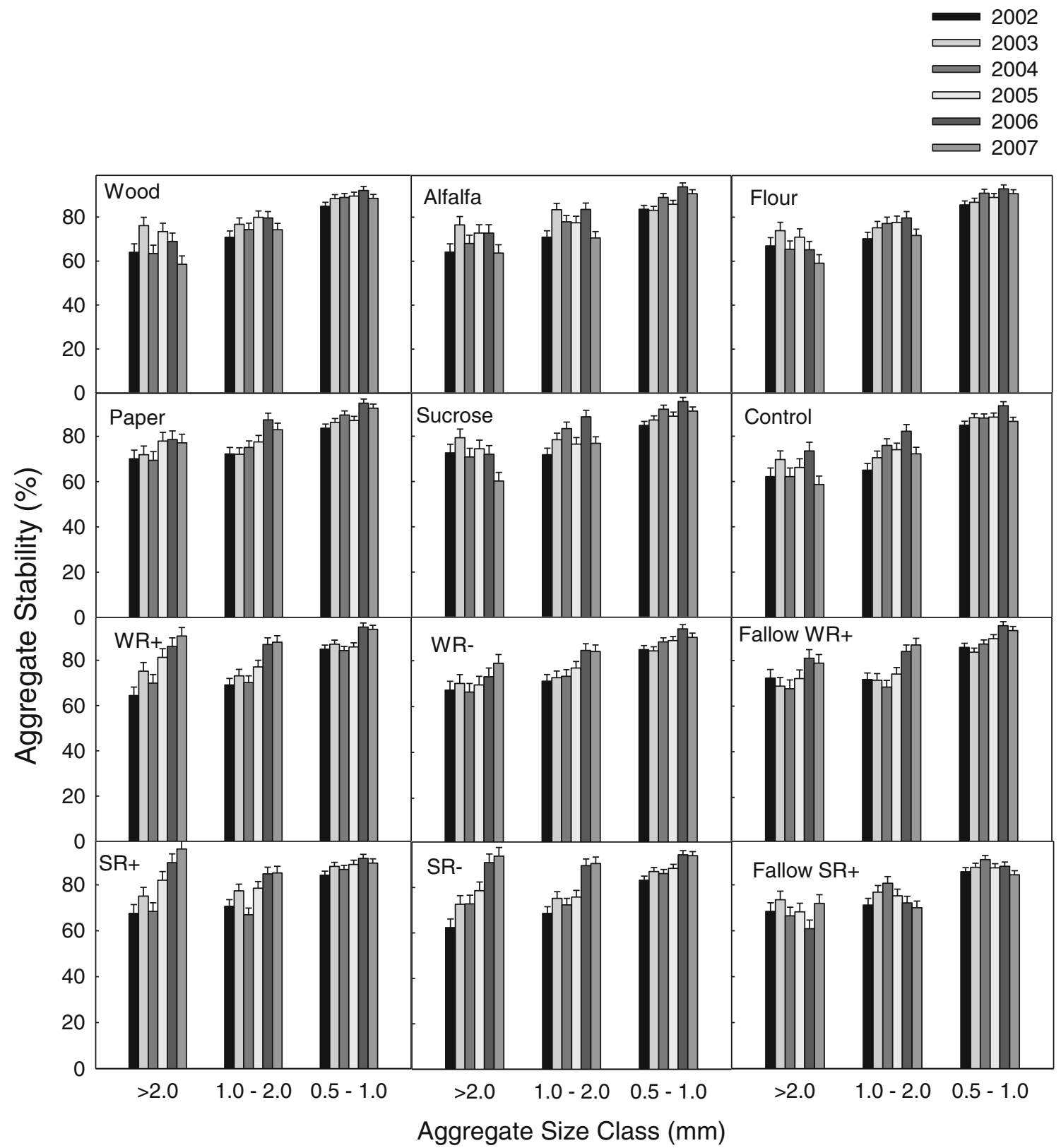

Fig. 3 Wet aggregate stability as a function of time and carbon source for the 0 - to 7.5 -cm soil depth

7.5- to $15-\mathrm{cm}$ soil depth increment, WAS in the 0.5 - to $1-\mathrm{mm}$ aggregate size class increased from 2002 to 2007 (year effect, $P<0.0001$ ) across $\mathrm{C}$ source treatments (Fig. 4). In the 1- to 2$\mathrm{mm}$ aggregate size class, WAS exhibited a year by treatment interaction $(P=0.006)$ with WAS increasing in the alfalfa, flour, sucrose, $\mathrm{WR}+, \mathrm{WR}-, \mathrm{SR}+, \mathrm{SR}-$, and fallowSR $+\mathrm{C}$ source treatments; decreasing in the fallowSR + treatment; and remaining the same in the wood, paper, control, and fallowWR $+\mathrm{C}$ source treatments. In the $>2$-mm aggregate size class, WAS exhibited a year by treatment interaction $(P=$ 0.018 ) with WAS increasing in the WR+, WR-, SR + , and $\mathrm{SR}-\mathrm{C}$ source treatments and remaining unchanged in the remaining $\mathrm{C}$ source treatments.
Growing season soil respiration in 2005 exhibited a treatment by time interaction $(P=0.0002)$. On day 173 , soil respiration in the $\mathrm{SR}+$ and $\mathrm{SR}-$ treatments was greater than in the remaining ten treatments (Fig. 5). On day 189, soil respiration had increased in the $\mathrm{SR}+$ and $\mathrm{SR}-$ treatments when compared to day 173 but was similar to day 173 in the remaining ten treatments. On day 195, soil respiration had declined slightly in the SR+ and SR- treatments while increasing in the remaining treatments with the order of soil respiration rate being $\mathrm{SR}+$ and alfalfa $>$ paper, WR-, fallowWR + , and SR $->$ wood, flour, sucrose, control, WR + , and fallowSR+. On day 244, soil respiration on average had declined and become less variable with the order of soil 


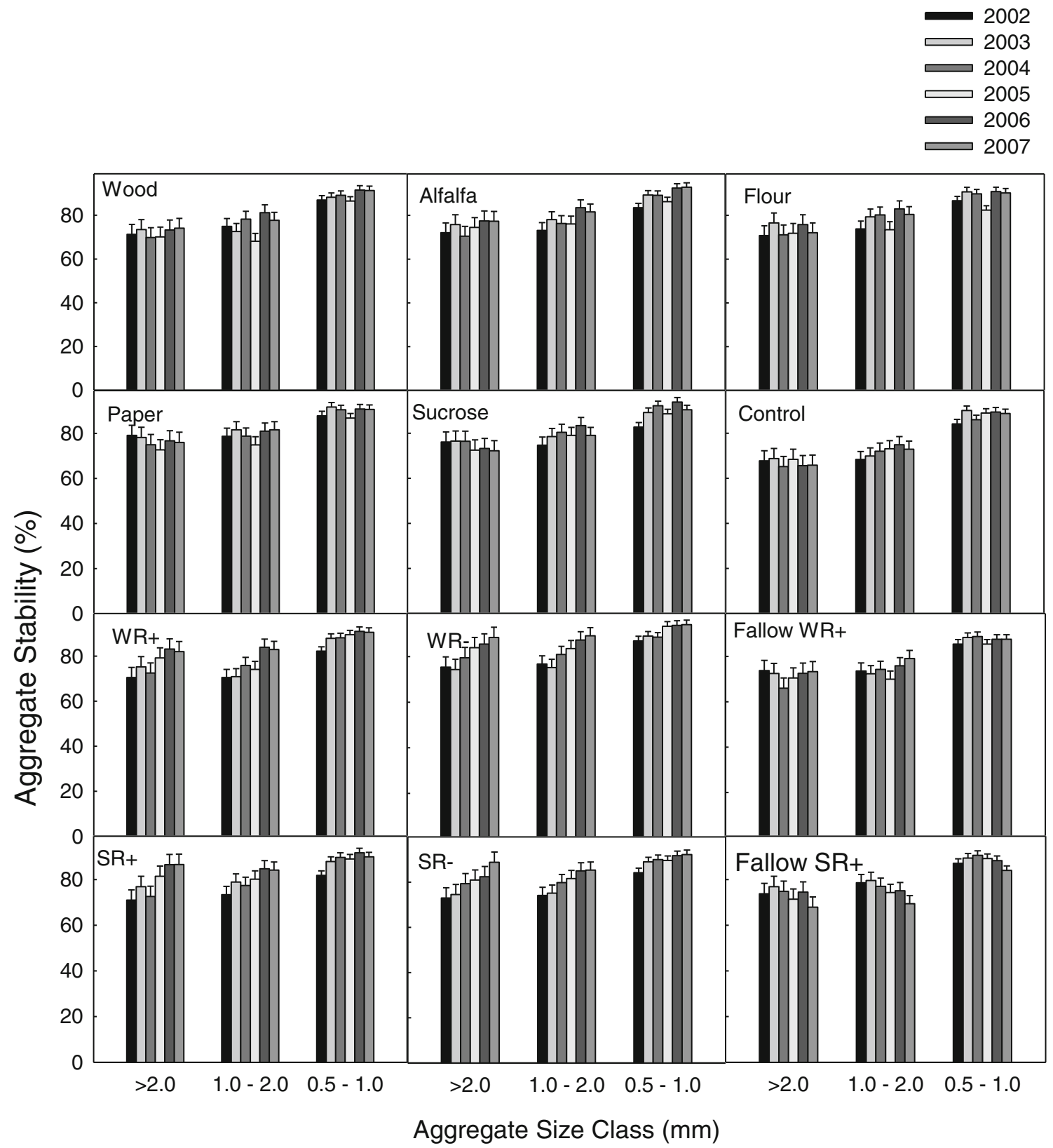

Fig. 4 Wet aggregate stability as a function of time and carbon source for the 7.5- to $15-\mathrm{cm}$ soil depth

respiration rate being $\mathrm{SR}+>\mathrm{SR}-, \mathrm{WR}->$ wood, alfalfa, flour, paper, sucrose, control, WR+, fallowWR + , fallowSR + . Near the end of the growing season, the $\mathrm{SR}+$ and $\mathrm{SR}-$ treatments exhibited higher soil respiration rates than the other ten treatments which exhibited soil respiration rates similar to those observed at the beginning of the growing season.

\section{Discussion}

From 2002 to 2007 , weather at the research site was variable but not extreme. It is unlikely that weather played a significant role in the outcome of this study. Wheat and switchgrass yields observed in this study were reasonable for the region. Similarly, a number of soil properties measured during this study exhibited statistically significant changes, but the magnitude of these changes likely had little effect on the results of this study. Bulk density changes from 2002 to 2007 were small with the exception of that in the $0-$ to $7.5-\mathrm{cm}$ depth increment, but none of the values would impede water movement, microbial activity, or plant root growth [1]. Soil EC and $\mathrm{pH}$ also exhibited statistically significant changes, but values were within the range suitable for microbial activity and plant growth [15]. Soil $\mathrm{N}$ concentration decreased in the surface soil increment, but soil $\mathrm{N}$ content increased due to increases in bulk density. Soils were not analyzed 
Fig. 5 Soil respiration during the 2005 growing season as a function of carbon treatment. The arrow on $x$-axis denotes date of wheat harvest and $\mathrm{C}$ source treatment application. Treatments include wheat with residue returned at harvest $(\mathrm{WR}+)$, wheat with residue removed at harvest (WR-), fallow with wheat residue added at harvest (fallow WR+), switchgrass with residue returned at harvest $(\mathrm{SR}+)$, switchgrass with residue removed at harvest ( $\mathrm{SR}^{-}$), and fallow with switchgrass residue added at harvest (fallow SR+)

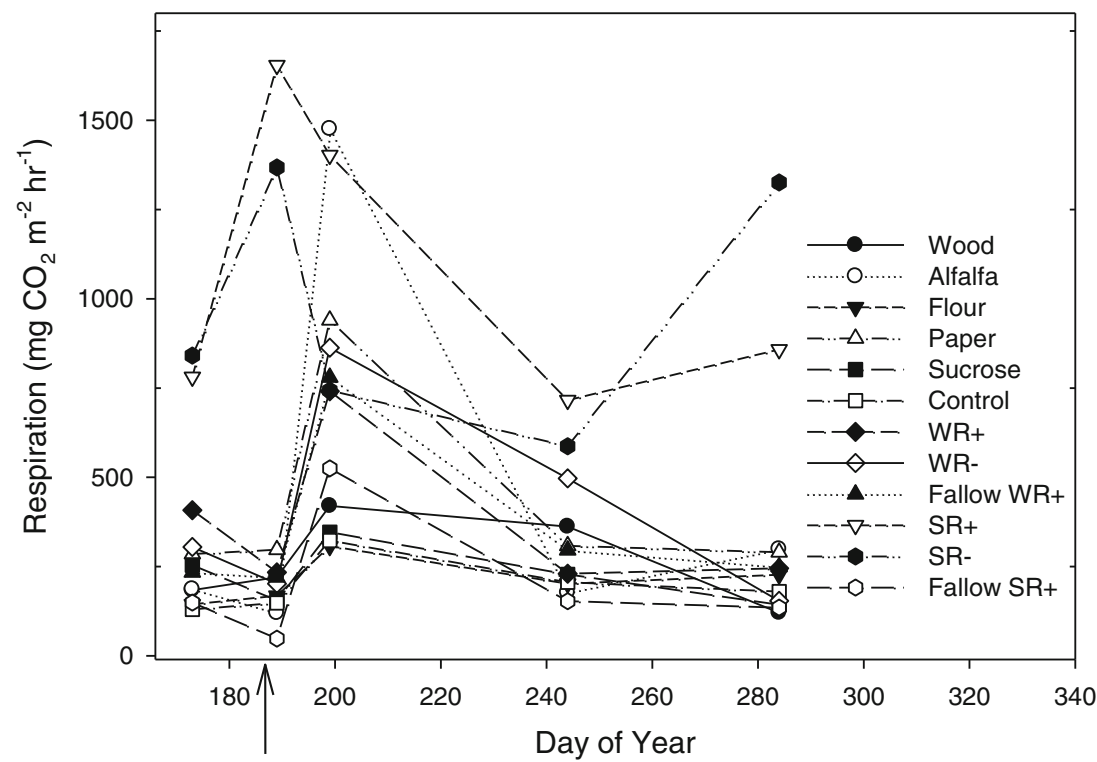

for inorganic $\mathrm{N}$, but we speculate that mineralization of organic $\mathrm{N}$ resulted in nitrate increases, and the increase in EC observed in lower depth increments was due to leaching of this inorganic $\mathrm{N}$.

The wood, alfalfa, flour, paper, sucrose, fallowWR+, and fallowSR $+\mathrm{C}$ source treatments were surface applied and represent energy sources of varying quality to soil microorganisms. Low-quality substrates tend to favor fungi while high-quality substrates tend to favor bacteria [3]. Based on visual observation of the plots, the rate at which these materials were utilized decreased in the order sucrose $=$ flour $>$ alfalfa $>$ paper $>$ wood $>$ fallowWR $+=$ fallowSR + . The visual observations are supported by the 2007 soil respiration results where the ranking of the treatments on day 195 , shortly after $\mathrm{C}$ source treatments were applied, were similar to the order of the treatments described above (Fig. 5). This variation in substrate utilization rate creates a gradient in the time microorganisms were utilizing applied $\mathrm{C}$ as an energy source. Hence, these surface $\mathrm{C}$ treatments likely influenced soil microorganism community structure and activity. Treatments that provided substrate for soil microorganisms for a longer period of time (e.g., wood, fallowWR+, and fallowSR+) maintained POM and TLC content while those that were utilized rapidly (e.g., sucrose) lost POM in the surface layer (Table 2). Maintaining POM and TLC in the wood, fallowWR + , and fallowSR $+\mathrm{C}$ source treatments maintained or increased total soil $\mathrm{C}$ as well. In contrast, the WR+, $\mathrm{WR}-, \mathrm{SR}+$, and $\mathrm{SR}-$ treatments provided soil microorganisms with substrate in the form of growing root material and root exudates throughout the growing season. In treatments with actively growing plants, POM was maintained and TLC increased resulting in a trend of increasing soil organic $\mathrm{C}$ in the WR+ and WR-treatments and an increase in soil organic $\mathrm{C}$ in the $\mathrm{SR}+$ and $\mathrm{SR}-$ treatments (Table 2). The greater change in soil $\mathrm{C}$ components and total soil organic $\mathrm{C}$ with the $\mathrm{SR}+$ and $\mathrm{SR}-$ treatments when compared to the $\mathrm{WR}+$ and $\mathrm{WR}$ - treatments is due to roughly fivefold more perennial switchgrass root biomass compared to annual wheat.

In addition to serving as a nutrient and energy source for soil biota, plant residue provides protection against wind and water erosion and serves as a boundary layer over the soil reducing evaporation. While erosion rates were not measured, soil loss was observed from some plots following high-intensity rains over the course of the study. Water erosion begins with detachment of soil particles resulting from raindrop impact. Raindrop impact also serves as a disruptive force for surface soil aggregates and likely contributed to the increase in bulk density observed in this study (Table 1). Wetting and drying cycles also disrupt aggregates, and the presence of a residue layer would reduce this effect. In the wood, alfalfa, flour, paper, sucrose, and control C source treatments, the soil surface was exposed to raindrop impact for much of each year, and MWD of soil aggregates in the $0-$ to $7.5-\mathrm{cm}$ soil increments declined $50 \%$ (Fig. 1). Not only did MWD decline in these treatments, but WAS declined or was unchanged (Fig. 2 and 3). When the soil surface was protected by plant residue (WR+ and $\mathrm{SR}+$ treatments), MWD exhibited year-to-year variation but was essentially unchanged over the course of the study (Fig. 1). In treatments where plants were grown and residue removed, changes in MWD were more complex. In the WR- treatment where an annual plant was grown, MWD was unchanged for 3 years and then declined. In the SR - treatment where a perennial plant was grown, MWD declined during the establishment year and then returned to values similar to that at the beginning of the study. In the four treatments where plants were grown and a root system was present, there was also a dramatic increase in WAS for aggregates $>2 \mathrm{~mm}$ for both soil 
depth increments (Fig. 2 and 3). In the fallowWR+, applied residue provided some protection, but there was a gradual decline in MWD over the course of the study (Fig. 1). In the fallowSR + treatment, MWD declined during the fallow period preceding application of the residue from the first crop and then returned to levels near what was present at the beginning of the study. Surface plant residue with no root inputs resulted in little or no change in WAS in either soil depth increment (Fig. 2 and 3).

The mechanism by which $\mathrm{C}$ is sequestered in soils has been much studied $[13,14]$. The generally agreed upon process is that when fresh residue comes into contact with the soil, microbial activity generates binding agents that results in formation of macroaggregates containing coarse POM. Over time, this coarse POM breaks down to form fine POM that becomes encrusted with clay particles and microbial products to form microaggregates. Eventually, the macroaggregate breaks down releasing microaggregates which are available to form subsequent macroaggregates [17]. It is the turnover of macroaggregates that results in an increase in stable microaggregates. Long-term sequestration of $\mathrm{C}$ in soils occurs when the $\mathrm{C}$ is chemically protected as in a chemical structure derived from the plant or microbial activity that resists decomposition, physico-chemically protected through adsorption to the mineral phase, or physically protected within interaggregate pores that cannot be accessed by decomposers (e.g., [13]). Rasse et al. [13] concluded that with the exception of the chemical protection mechanism, SOM protection is enhanced by root activities.

Results from our study support this model. In treatments where $\mathrm{C}$ sources were surface applied, soil microorganisms would have utilized them as an energy source, and the main $\mathrm{C}$ input to the soil would have been microbial by-products. The wood, fallowWR+, and fallowSR+ treatments increased TLC, and wood and fallowSR+ treatments increased TOC in this study. For the wood, alfalfa, paper, fallowWR+, and fallowSR $+\mathrm{C}$ source treatments, there would have been potential for incorporation of POM by soil biota as well, but there were no increases in POM in the surface applied treatments. Fungi produce by-products that decompose more quickly than bacterially produced by-products [8]. In addition, fungi are favored when low-quality substrates are present and bacteria are favored when high-quality substrates are present [3]. We speculate that substrates such as wood, wheat residue, and switchgrass residue would have more fungi relative to bacteria than substrates such as sucrose, starch, and paper. The wood, wheat residue, and switchgrass residue treatments provided substrate for a greater portion of the year than did the sucrose, starch, and paper treatments as well. These surface applied substrate effects on soil microbial composition and activity resulted in an increase in TLC and TOC during this study. In treatments where there were actively growing roots, we observed increases in TLC. Switchgrass produced greater amounts of root biomass, and in these treatments, TOC increased.

\section{Conclusions}

Plant residue protects the soil from wind and water erosion and serves as a substrate to sustain soil biota [21]. Results from this study show that both roles are essential to maintaining or improving soil structure and SOM. Soils receiving $\mathrm{C}$ sources that varied in quality and placement decreased POM with surface application of readily available substrate, exhibited higher TLC and TOC content with plant residue C source additions, maintained MWD with plant residue additions, and exhibited increased WAS where live plants were growing. Surface plant residue protected the soil against raindrop impact and reduced the intensity of wetting and drying cycles allowing the development of larger more stable aggregates resulting in $\mathrm{C}$ accrual. Providing soil biota with an energy source alone resulted in a reduction in MWD and components of SOM. Plant residue protected the soil from raindrop impacts and when combined with root inputs resulted in an increase in TLC and TOC. As residues are identified for other uses, such as animal feed or biofuel feedstocks, residue retention will have to be sufficient to meet soil conservation needs [22].

\section{References}

1. Arshad MA, Lowery B, Grossman B (1996) Physical tests for monitoring soil quality. In: Doran JW, Jones AJ (eds) Methods for assessing soil quality. SSSA, Madison, pp 123-141

2. Blake GR, Hartge KH (1986) Bulk density. In: Klute A (ed) Methods of soil analysis part 1: physical and mineralogical methods, 2nd edn. Am Soc Agron, Madison, pp 363-375

3. Bossuyt H, Denef K, Six J, Frey SD, Merckx R, Paustian K (2001) Influence of microbial populations and residue quality on aggregated stability. Appl Soil Ecol 16:195-208

4. Cambardella CA, Gajda AM, Doran JW, Wienhold BJ, Kettler TA (2001) Estimation of particulate and total organic matter by weight loss-on-ignition. In: Lal et al (eds) Assessment methods for soil carbon. Lewis Publishers, Boca Raton, pp 349-359

5. Johnson JMF, Barbour NW, Weyers SL (2007) Chemical composition of crop biomass impacts its decomposition. Soil Sci Soc Am J 71:155-162

6. Kemper WD, Rosenau RC (1986) Aggregate stability and size distribution. In: Klute A (ed) Methods of soil analysis: part 1physical and mineralogical methods. American Society of Agronomy-Soil Science Society of America, Madison, pp 425442, SSSA book series 5.1

7. Littell RC, Milliken GA, Stroup WW, Wolfinger RD (1996) SAS system for mixed models. SAS Institute, Inc., Cary

8. Martin JP, Haider K (1979) Biodegradation of ${ }^{14} \mathrm{C}$-labelled model and cornstalk lignins, phenols, model phenolase humic polymers, and fungal melanins as influenced by a readily available carbon source and soil. Appl Environ Microbiol 38:283-289 
9. National Renewable Energy Laboratory (1995) Determination of acid insoluble lignin in biomass LAP-003. In: Standard biomass analytical methods, NREL Laboratory Analytical Procedures. Vol. 2003. National Renewable Energy Laboratory, Golden, CO

10. National Renewable Energy Laboratory. 1996a. Determination of acid soluble lignin in biomass LAP-004. In. Standard biomass analytical methods, NREL Laboratory Analytical Procedures. Vol. 2003. National Renewable Energy Laboratory. Golden, CO

11. National Renewable Energy Laboratory (1996b) Determination of carbohydrates in biomass by high performance liquid chromatography LAP-002. In: Standard biomass analytical methods, NREL laboratory analytical procedures. Vol. 2003. National Renewable Energy Laboratory, Golden, CO.

12. Perlack RD, Wright LL, Turhollow AF, Graham RL, Stokes BJ, Erback DC (2005) Biomass as a feedstock for a bioenergy and bioproducts industry: the technical feasibility of a billion-ton annual supply. NTIS, Springfield, DOE/GO-102005-2135 and ORNL/TM-2005/66; http://feedstcokreview.ornl.gov/pgf/billion ton_vision.pdf, Accessed 26 January 2010

13. Rasse DP, Rumpel C, Dignac M-F (2005) Is soil carbon mostly root carbon? Mechanisms for a specific stabilization. Plant Soil 269:341-356

14. Six J, Frey SD, Thiet RK, Batten KM (2006) Bacterial and fungal contributions to carbon sequestration in agroecosystems. Soil Sci Soc Am J 70:555-569
15. Smith JL, Doran JW (1996) Measurement and use of pH and electrical conductivity for soil quality analysis. In: Doran JW, Jones AJ (eds) Methods for assessing soil quality. SSSA, Madison, pp 169-185, SSSA Spec. Publ. 49

16. Smucker AJM, McBurney SL, Srivastava AK (1982) Quantitative separation of roots from compacted soil profiles by hydropneumatic elutriation systems. Agron J 74:500-503

17. Tisdall JM, Oades JM (1982) Organic matter and water-stable aggregates in soils. J Soil Sci 33:141-163

18. Weil RR, Islam KR, Stine MA, Gruver JB, Sampson-Leibig SE (2003) Estimating active carbon for soil quality assessment: a simplified method for laboratory and field use. Am. J. Alt. Agric. $18: 3-17$

19. Wienhold BJ, Gilley JE (2010) Cob removal effect on sediment and runoff nutrient loss from a silt loam soil. Agron J 102:14481452

20. Wienhold BJ, Varvel GE, Jin VL (2011) Corn cob residue carbon and nutrient dynamics during decomposition. Agron J 103:11921197

21. Wilhelm WW, Johnson JMF, Hatfield JL, Voorhees WB, Linden DR (2004) Crop and soil productivity response to corn residue removal: a literature review. Agron J 96:1-17

22. Wilhelm WW, Johnson JMF, Karlen DL, Lightle DT (2007) Corn stover to sustain soil organic carbon further constrains biomass supply. Agron J 99:1665-1667 